\title{
Article
}

\section{Teaching during COVID-19: The Decisions Made in Teaching}

\author{
Liina Lepp, Triinu Aaviku *, Äli Leijen $\mathbb{(}$, Margus Pedaste $\mathbb{1}$ and Katrin Saks \\ Institute of Education, University of Tartu, 50103 Tartu, Estonia; liina.lepp@ut.ee (L.L.); ali.leijen@ut.ee (Ä.L.); \\ margus.pedaste@ut.ee (M.P.); katrin.saks@ut.ee (K.S.) \\ * Correspondence: aavikut@gmail.com
}

check for updates

Citation: Lepp, L.; Aaviku, T.; Leijen,

1.; Pedaste, M.; Saks, K. Teaching during COVID-19: The Decisions Made in Teaching. Educ. Sci. 2021, 11, 47. https://doi.org/10.3390/ educsci11020047

Academic Editors: Lindsay Clare Matsumura and Palitha Edirisingha Received: 29 December 2020

Accepted: 26 January 2021

Published: 28 January 2021

Publisher's Note: MDPI stays neutral with regard to jurisdictional claims in published maps and institutional affiliations.

Copyright: (c) 2021 by the authors. Licensee MDPI, Basel, Switzerland. This article is an open access article distributed under the terms and conditions of the Creative Commons Attribution (CC BY) license (https:// creativecommons.org/licenses/by/ $4.0 /)$.

\begin{abstract}
The emergency caused by COVID-19 and the transition to distance learning has made teachers face novel decision-making situations. As the teachers' pedagogical decisions have an impact on the students' learning experience, the aim of this study was to describe and explain what influenced the teachers' teaching-related decisions and how these decisions were reflected in the teaching process during distance learning. The study was based on semi-structured interviews with 16 Estonian basic school science teachers. The data were analyzed using qualitative thematic analysis. The results show that teachers' teaching-related decisions were influenced by factors that were related to the existence of digital tools as well as to the ability to use them purposefully in the home settings of teachers and students. Teachers' teaching decisions were mostly motivated by short-term goals, such as maintaining students' social interaction and supporting student motivation. The desire of teachers to keep students' and teachers' own workload affordable was also considered as a factor influencing teachers' teaching-related decisions. According to the interviews, the switch of focus to workload and well-being and valuing socialization and student motivation over subject matter competences seems to be unique for this new situation.
\end{abstract}

Keywords: distance learning; COVID-19; teaching and learning in emergencies; science teachers; qualitative research

\section{Introduction}

Due to the wide spread of a new Coronavirus called SARS-Cov-2 [1], school buildings around the world were closed in 2020 to protect students and teachers from the spread of the disease [2] and learning was reorganized for distance learning. This change in the organization of education put teachers, students and their parents in a new situation. Although it is too early to assess the long-term impact of COVID-19 in education, various COVID-19 education-focused studies have been conducted in recent months. For example, studies by Cullinane and Montacute [3] and Schuck and Lambert [4] confirmed that the availability of technological facilities in students' homes is a major concern in the transition to distance learning. It was found that economic inequality in the home hindered students' ability to participate effectively in their studies. Moreover, the preparation of schools for the use of technology has also influenced the success of distance learning. In schools where digital learning platforms and digital tools were used before COVID-19, the transition to distance learning was also easier [5,6].

In addition to distance learning research related to the existence of technology, COVID19 research in the field of education has also focused on preparing teachers to cope with distance learning. For example, Gudmundsdottir and Hathaway [7] found in a study of 574 Norwegian and 239 US teachers that teachers had little previous (pre-distance) online teaching experience. Specifically, $67 \%$ of Norwegian teachers and $92 \%$ of US teachers did not have previous online teaching experience. The lack of adequate preparation for online teaching was also highlighted. At the same time, teachers expressed a positive attitude and readiness to make an effort to cope successfully with the transition to distance learning in new circumstances, or as Gudmundsdottir and Hathaway [7] p. 244 say "they were willing 
to go the extra mile to move teaching to online platforms", meaning teachers were willing to "take an agentic stance" to find ways to cope with a challenging new distance learning situation. Moreover, in a survey of 325 US K-12 teachers, Trust and Whalen [8] found that teachers lacked both preparation and support in using technology to design quality instruction during the transition to distance learning. At the same time, $61 \%$ of teachers felt overwhelmed with all the online learning tools and resources available. According to the study, it was difficult for teachers to find suitable digital tools to support learning and communication with students during the distance learning period.

Besides technological and pedagogical readiness, teacher well-being and work-related stress have also been addressed in previous studies. It has been found that uncertainty about how long-distance learning lasts and in what way distance learning should be taught (lack of clarity around the plans) is stressful for teachers. Teachers in the study by Kim and Asbury [9] (p. 1070) have described insecurity at the beginning of a distance learning period as "like a rug had been pulled from under you". In addition to the general uncertainty, a study of 600 language teachers [10] shows that for teachers, increased workload (workload as a stress factor) was the most stressful during distance learning (mentioned as the main source of stress). The study also showed that the loss of control over work (rated above 3 out of 4) blurred lines between home and work, and irregular working hours (rated above 2.5 out of 4 ) were stressful for teachers during the distance learning period. Besides, a study by Trust and Whalen [8] found that teachers' perceived work stress is related to both insufficient preparation for online teaching and a lack of support for teachers' online teaching.

Thus, previous research shows that the availability of appropriate technological solutions [3] as well as the experience of schools in their implementation [5] affect students' learning experiences during distance learning. Moreover, pedagogical readiness and preparedness for distance learning in general and online teaching more specifically $[7,8]$, and teacher wellbeing and coping with uncertainty seem to be important [8-10]. This means that various individual and environmental factors have been identified as important in this new context, while the traditional/long-term purposes of education (see also [11]) seem to have much less focus. Moreover, it is not clear how exactly these are diverse factors considered by teachers while making decisions related to teaching in the context of distance learning due to COVID-19 and which of the factors have more weight in the decision-making process. Teachers' pedagogical decisions have an impact on the students' learning experience and thus the study of decision-making processes is very relevant in the changed circumstances. Consequently, it is important to find out how the transition to distance learning due to COVID-19 has influenced teachers' decision-making processes and how teachers themselves justify their teaching decisions. Thus, the aim of the current study is to describe and explain what influenced the teachers' teaching-related decisions and how these decisions were reflected in the teaching process during distance learning. The study is conducted in Estonia where the K-12 students have shown very high results in international comparison tests such as PISA [12]. Furthermore, previous studies have indicated that teachers in Estonia are highly educated (the teacher's qualification requirement is a master's degree), very experienced and possess a high level of knowledge about teaching (e.g., $[12,13])$. Therefore, it is an interesting context to explore teachers' decision-making in more detail and to inform international community of researchers.

In the following chapters, we firstly concentrate on the decision-making of teachers and present the research questions. Next, the context of distance learning in Estonia is described. Subsequently, the qualitative research methodology is introduced, followed by the presentation of the research results, discussion of the main results and the conclusion.

\subsection{Teachers' Teaching-Related Decision-Making}

Teaching is essentially a thinking practice [14], a complex activity that involves continuous decision-making processes in the teaching planning stage, the interaction phase in teaching and in the analysis following the teaching process. It means that teachers are 
supposed to have a high degree of decision-making autonomy while planning the teaching activities as well as during teaching situations. Therefore, the students' learning experience, or as Vanlommel, Van Grasse, Vanhoof and Petegem [15] (p. 75) say “the progress of pupils' educational trajectories", depends on teachers' decisions.

The basis for teachers' teaching-related decisions lies in their professional knowledge, which is divided into content knowledge (teacher's subject-specific knowledge), pedagogical content knowledge (understanding how to teach a subject-specific topic to students) and general pedagogical knowledge (knowledge about learners and learning, principles of classroom management and educational purposes in general) [16]. To effectively support student development, it is important that teachers have knowledge of students' cognitive functioning, including emotional, social, and behavioral development [17,18]. Moreover, teachers' knowledge of student motivation and their ability to create conditions that promote students' self-motivation are essential [18]. In addition, Mishra and Koehler [19] combined technology knowledge into the TPCK model (Technological Pedagogical Content Knowledge Framework) with the aforementioned teachers' professional knowledge and its components. In other words, how to teach a specific subject with the help of technology plays an important role in teachers' knowledge, as well as teachers' ability to make the available technological tools suitable for the learning process [19]. The elaborated use of technological, pedagogical and subject knowledge enables teachers to decide on the general approach to teach the whole class and each individual student and to make decisions to support student learning in the most effective way possible [16,18,19].

Besides teachers' professional knowledge, their teaching-related decisions are influenced by their own beliefs $[20,21]$. According to previous studies, the teachers' pedagogical beliefs are based on their own experience as students, experience in teacher training and are also influenced by daily teaching practices. Teachers prefer what they believe is valuable, in their choice of learning objectives and content [22]. In addition to the teachers' knowledge and personal experience, the expression of beliefs in practice is also influenced by students' characteristics, school environment, and broader social and pedagogical background (e.g., pedagogical traditions in the country) [23,24]. However, research also shows inconsistencies between teachers' beliefs and practices. For example, a survey conducted among Estonian science teachers revealed that although teachers highlight the value of constructivist learning and practical activities in the lesson, it is not always reflected in their teaching practice [25].

On top of professional knowledge and beliefs, teachers' decision-making is influenced by their purposes. These could be individual or collective (shared among colleagues) longand short-term purposes. For example, research on collective efficacy [26] has indicated the shared visions being related to students' learning outcomes. Biesta [11] suggests distinguishing between three broad (long-term) purposes of education: qualification, socialization and subjectivization. Qualification entails ensuring that students completing a certain level of education have reached a certain level of competences, e.g., they are qualified for the next stage of education. Socialization means that students need to be prepared for successful functioning in society, this would entail good social skills and finding one's position in society. The third purpose means that education should support each student to find out who they are and what they would like to do in their life. This purpose is often closely related to supporting individual students' strengths and talents. The described long-term purposes also guide teachers' short-term goals related to teaching. For example, decisions related to classroom management, supporting students' motivation and finding best practices for explaining complex subject matter content.

Furthermore, teachers' teaching decisions (as already mentioned in the section on beliefs) are influenced by environmental factors. Aho, Haverinen, Juuso, Laukka and Sutinen [27] (p. 400) aptly stated that "A teacher cannot escape the world outside when closing the classroom door. Teaching is influenced by the surrounding society, culture and traditions". For example, teachers' decision-making is influenced by educational policies and various framework documents that guide the organizing of teaching, as well as more 
narrowly by the community—school management and colleagues—enforcing or hindering activities $[28,29]$. In addition, cooperation with students' parents and the wider community is also important. A well-functioning relationship with parents allows the teacher to set common goals with the parents to support the children [30]. Lastly, teaching decisions are also influenced by different material resources (e.g., classroom sizes, school furniture; availability of technical equipment).

To sum up, teachers' decisions are related to their individual resources (including teachers' knowledge of students and learning) and their long- and short-term purposes. On the other hand, external environmental factors influence the decision-making processes (see also [31]). It is essential to consider that the process of teaching and learning is very complex and its different parts interact with each other in a dynamic way. Therefore it is also important to find out how exactly these diverse factors are considered by teachers while making decisions related to teaching in the context of distance learning due to COVID-19, which of the factors have more weight in the decision-making process and how it could influence teaching and learning processes. Consequently, the following research questions were posed for the current study:

1. What do teachers point out as important factors influencing their teaching-related decisions during distance learning?

2. How were these decisions reflected in the teaching process during distance learning based on teachers' explanations?

The starting positions of the transition to distance learning due to COVID-19 differ in countries and the context is also known to influence teaching decisions. For that reason, we will move on to the Estonian context, in which we briefly introduce the transition to distance learning and describe the background factors that influenced the transition.

\subsection{The Context of Distance Learning in Estonia}

In March 2020, an emergency was imposed in Estonia, a country that has just 1.3 million people, in connection with the spread of COVID-19. Teachers were given one day (the last school day of the week, Friday) to agree on further activities and tasks with students and students were given a chance to get necessary tools (e.g., laptops) and materials (e.g., books, workbooks) from school. Starting from 16 March 2020 all schools in Estonia were closed down by the order of the government with a purpose to prevent people from gathering and reduce the spread of the virus. Therefore, with one workday of advance notice, 153,155 students of general education schools (grades 1-12) and 15,843 teachers from 516 schools [32] started with distance learning. According to the Basic Schools and Upper Secondary Schools Act [33] as well as curricula regulations [34], distance learning is guided learning (including e-learning) that is focused on acquiring knowledge and skills, but is not carried through in the school building. Thus, it was the government's command that teachers were obliged to continue working towards goals set in the curriculum in conditions where learning takes place from a distance instead of classroom training - that meant that the students as well as teachers were working from home and keeping in touch through digital means. When distance learning first came into force, it was for the period of two weeks, which was then extended up until the end of the school year (June 2020). The improved situation of COVID-19 has allowed the students to go to school in small groups since mid-May of 2020, which was mainly to help the students who had not participated in distance learning during the lockdown. In the new situation, the teachers were expected to continue working with both the students in distance learning conditions and support those in need of individual tutoring in classroom conditions.

During the period of switching over to distance learning, The Ministry of Education and Research [35] provided the teachers as well as school leaders with several kinds of guidelines on how to teach as well as support teachers during the distance learning period. For example, teachers were advised to avoid numerical grading in the first two weeks and use verbal grading to give feedback and motivate students. It was also suggested to give the students more time to complete their tasks and the teachers were encouraged to think 
about the possibilities for supporting the students' social interaction [35]. The ministry recommended keeping the number of different digital environments and resources used for exchanging information and schoolwork to a minimum. In a formal notice to the teachers, it was also said that "students, their learning habits and ability to work independently as well as the opportunities of the parents are different-take that into account when setting up learning goals" [35] (p. 1). Specific choices on learning methods and environments were up to decide on for the teachers and school leaders. However, it was recommended to gather systematic feedback from the students and their parents and take it into account while planning and conducting the teaching. Overall, the guidelines focused more on preserving the well-being of students and encouraged teachers to consider the well-being of the parents as well. The well-being of teachers was primarily discussed over social media (according to the authors) where on the one hand, parents criticized teachers for too little guidance and feedback, and on the other hand, teachers justified their actions with the increase of workload due to the distance learning conditions. However, on the international level, the importance of providing emotional support to faculty as well as students during distance learning was emphasized in the OECD framework [36], which aims to support educational decisions in order to implement effective responses to the COVID-19 pandemic in education.

Similarly to other countries' education systems, the transition to distance learning in Estonia also meant putting the digital capabilities of the country to the test. Estonia is often brought out as an example of a digitally capable society where the IT-infrastructure as well as national e-services are one of the best in the world (considering both the amount as well as quality) [37]. Furthermore, the transition to distance learning was supported by the Estonian Lifelong Learning Strategy 2020 [38] agenda where one of the highlighted priorities is "A digital focus on lifelong learning". Already in 2014, one of the goals in that strategy was to use modern digital technology to learn and teach more effectively and efficiently, to improve the digital skills of the whole population and to ensure access to the new generation of digital infrastructure. Therefore, on a national level, efforts in the name of students as well as teachers being digitally competent have been made for years.

In the following, two of the greatest educational technology solutions are presented, which, according to the authors, supported the transition to distance learning in Estonia. Of the functioning digital technologies, Estonian schools have been using web applications eKool (eSchool, https: / / ekool.eu) or Stuudium (stuudium.com) or similar solutions for over a decade. These aforementioned applications enable information exchange between homes and the school - the information is shared by teachers, students and parents. All of the students' homework, grades and feedback are added onto eSchool/Stuudium; messages are sent to learners, teachers and parents personally, as well as to groups of them. It is also possible to upload documents to the site, for example assignments. Therefore, when entering the distance learning period, Estonia was already well-equipped with a platform for information exchange with the students and parents.

E-Schoolbag, as the second educational technology solution supporting both teachers and students during the distance learning period, is an online library or repository with hundreds of educational resources. In that portal teachers can create and share materials (e.g., presentations, worksheets, tests) and the portal also has a collection of digital learning materials from different publishing houses. Therefore, all in all, teachers had the possibility to use free e-books and e-workbooks as well as resources created by other teachers already from the beginning of the distance learning period. The Estonian Lifelong Learning Strategy 2020 [38] also focuses on ensuring digital learning resources in schools, meaning that teachers and students are given access to high-quality e-books, e-workbooks and web-based grading tools as well as open source learning materials. Thus, the development of the E-Schoolbag has been one of the national educational priorities in Estonia.

Therefore, several conditions for using technological solutions in teaching have been provided, nevertheless, there are a number of issues in the usage of digital tools in the field of education. For example, when looking at previous research done on the topic of teachers 
using digital resources in their work, it can be said that teachers use digital resources less rather than more [39]. The research (although, the research was conducted more than three years ago) found that $89 \%$ of the teachers used the e-Schoolbag digital resources once a month or even less. Estonian teachers mostly use their own worksheets as digital resources ( $87 \%$ of those who replied) and create slideshows ( $78 \%$ of those who replied) but are rather modest about sharing them publicly.

When using different digital solutions, teachers' attitude towards using digital tools as well as their own digital competence is of great importance. It emerged from the Teaching and Learning International Survey TALIS 2018 conducted by OECD [40] that only $52 \%$ of teachers in Estonia who have graduated university in the last five years feel prepared to use ICT tools to teach their subject and just over a half of the teachers (53.1\%) marked that they are able to support their students through digital technology. According to the same survey, only a little over a half $(63.1 \%)$ of the school principals in Estonia believe that most of the teachers in their school feel confident using ICT tools in teaching. Furthermore, the results of the Leppik et al. [39] research show that teachers perceive their digital competences as rather poor. Then again, the Teacher Professional Qualification Standards [41] clearly state that Estonian teachers are expected to use digital technology in a meaningful way as well as to support students in their use of digital technologies.

Therefore, in addition to being digitally competent themselves, the teachers are expected to develop the digital competence of their students. The importance of developing students' digital competences is brought out in the National curriculum for basic schools [34] (p. 3) as "a general competence-a competence whose establishment is monitored and guided by the teachers' cooperation as well as the home-school partnership". On the other hand, Leppik et al. [39] found that the organizing of how digital skills are taught in Estonian general education schools is uneven-digital skills are already taught in the first school level (grades 1 to 3, ages 7 to 9) in about one fifth of the schools and in about half of the schools digital skills are taught as a separate subject in the 2nd and 3rd school levels (grades 4 to 9). Although, the same research acknowledges that a quarter of the teaching workforce does not agree with the statement that using digital tools should be a natural part of all subjects. According to Tire et al. [42], Estonian teachers guide their students to use digital tools to do their homework rather than using the tools in school lessons.

In the context of science education, which is the scope of the current study, use of digital tools was studied in 2016. More specifically, a cross-sectional study of Adov et al. [43] revealed that about half of the students aged 12 to 15 belong to a group that does not use smartphones and tablets (the digital devices that $97 \%$ of learners have at their hand) regularly in learning science or math. In contrast, there is only a small group of learners $(5 \%)$ that uses them on a daily basis in different learning assignments, for searching information, communication, and content creation. About one fifth of the students use their devices in learning only for information retrieval. In related studies it has been shown that the students' use of digital tools could be predicted strongly by teachers' attitudes towards technology [44]. Thus, teachers' attitudes and decision-making processes are extremely important in guiding learners towards effective use of technology and it cannot be underestimated in the COVID-19-related distance education settings, either.

The students think, according to the PISA questionnaire that was conducted among 15-year old Estonian students in 2018 [42], that they are in general satisfied with their digital skill set and their opportunities to use digital tools; $93 \%$ of Estonian students use a mobile phone as their primary digital tool and $73 \%$ use a laptop, almost all homes have access to the internet and only $3-5 \%$ of the students said they have no access to the internet at home. However, if teachers do not guide students to use their devices for learning, they are mainly used for other purposes, e.g., entertainment and socialization.

To sum up, it can be said that Estonia had a rather good starting position with eSchool/Stuudium as information exchange environments and the chance to use digital learning materials of eSchoolbag as well as with the fact that students had good access to internet connection and digital technologies. Then again, although previous studies 
have shown that Estonian teachers possess a high level of knowledge about teaching (e.g., [12,13]), they are not that confident about their digital competences and their habits of using information and communication technology. It is interesting how the described background influenced teachers' teaching decisions when switching to distance learning.

\section{Methods}

\subsection{Sample}

This study was based on semi-structured interviews with 16 Estonian basic school science teachers. Four participants were found by sending a letter to the mailing list of Estonian science teachers. The remaining 12 science teachers were found through personal contacts with researchers using a convenience sampling strategy. Basic school level science teachers with a minimum of 0.5 workload were involved in the study. Potential participants were contacted via email or phone.

The teachers involved in the study taught the following subjects (sometimes one teacher taught more than one) at basic school level: science, biology, chemistry, geography, physics. In most cases, teachers taught three subjects in grades 6-9 (students are usually aged 12-16 in these grades). Participants worked in a total of 18 schools (during the interview period), including two teachers teaching in several schools; two teachers from the same school participated. Among the schools there were large schools (with more than 800 students) as well as small schools (fewer than 100 students) and also two private schools. Class sizes varied from classes with 6 students to classes with 26 students. In most cases, the teachers who participated taught in classes with 20-24 students. Of the 16 teachers who participated in the study, 9 were women and 7 were men. The average work experience of the teachers was 13 years, further background information of the teachers is presented in Table 1 using pseudonyms.

Table 1. Background information of the teachers participating in the study.

\begin{tabular}{cccc}
\hline Interviewee & Age & $\begin{array}{c}\text { Years of Experience as a } \\
\text { Teacher }\end{array}$ & $\begin{array}{c}\text { Duration of the Interview } \\
\text { (In Minutes) }\end{array}$ \\
\hline Tania & 54 & 28 & 44 \\
Martin & 31 & 7 & 59 \\
Mary ${ }^{1}$ & 34 & 12 & 57 \\
Mark & 31 & 6 & 54 \\
Leo & 37 & 7 & 48 \\
Elisa & 28 & 2 & 56 \\
Henry & 23 & 1 & 80 \\
Evie 1 & 54 & 35 & 51 \\
Eric & 39 & 15 & 35 \\
Ella & 34 & 10 & 65 \\
Alma & 39 & 16 & 29 \\
Alan & 63 & 19 & 90 \\
Hilary & 28 & 4 & 73 \\
Harriet & 28 & 5 & 60 \\
Aron & 30 & 7 & 47 \\
Alla & 55 & 30 & 80 \\
\hline
\end{tabular}

${ }^{1}$ Work in the same school.

\subsection{Data Collection and Analysis}

The data were collected during the period of April-May 2020 using semi-structured interviews. By that time, teachers had been teaching from a distance for at least one month (from 16 March 2020) and it was known that distance learning would continue until the end of the school year (beginning of June in Estonia). Before conducting the interviews, the interview plan was discussed among the experienced researchers and a pilot interview was conducted with one of the science teachers who met the sampling criteria (the interviewee Tania). As no significant changes were made to the interview plan, the data of the pilot interview were included in the main dataset of the study. 
The interview plan with open-ended questions consisted of the following parts: (1) introductory warm-up questions (e.g., how has distance learning gone? Why so?); (2) background information questions (e.g., work experience as a teacher, classes taught, and subjects); and (3) a description of the process of planning and conducting the teaching with justifications (including factors influencing the decision-making) (e.g., how do you teach in a distance learning situation? Why did you make such a choice(s)? What influenced your decisions?). Finally, the interviewees were offered the opportunity to add more about distance learning and teaching at their own request (question: what else do you want to say about distance learning and teaching?) The main questions of the interview were supplemented with follow-up questions (e.g., an explanatory question: can you expand this a little further?) depending on the interview situation.

As there was an emergency situation (due to COVID-19) in Estonia during the interview period and it was recommended to keep the contacts to a minimum, the interviews were conducted in agreement with the interviewees using the web-based video conferencing tool Zoom. Firstly, the interviewees were introduced to the purpose of the interview and ethical issues were explained (confidentiality, data retention and further use), the structure of the interview was introduced as well. The interviewees were then asked for permission to record the interview. All interviews were recorded with the consent of the subjects. The interviews were conducted by five researchers and lasted from 29 to $90 \mathrm{~min}$ (average $58 \mathrm{~min}$ ). All the interviews were transcribed verbatim. To protect the participants identities, participants and their schools were given pseudonyms.

The data analysis relied on the techniques of qualitative thematic analysis [45] and was supported by the web based interactive software package QCAmap (www.qcamap.org). QCAmap made it possible to mark the thematic units, add themes next to thematic units and to later categorize themes. In addition, the environment made it possible to extract data from coded and categorized data. The data analysis environment also allowed the use of an Inter-Coder function, which allowed two researchers to perform separate coding, discuss coding and categorization decisions.

After uploading the data, the first two authors of the article read the interviews repeatedly in order to map the initial themes-thematic units (the themes/parts of the text that conveyed the whole idea, which could be a paragraph, sentence or part of a sentence) that were related to the research question. The researchers added initial themes next to the marked part of the text. After the initial coding, the researchers then moved back to the beginning of the dataset and analyzed each previously marked section in more detail, generating primary labeled theme(s). After the initial analysis, the researchers reviewed the labeled themes and, if necessary, clarified the scope of marking as well as the names of the themes. For example, the text in the transcript of the interview "I am in a very good situation, as I went to the school's computer teacher and they set up a second monitor for me, so I work from home with two screens and I also have a document camera. I am not complaining, I have the technical tools (Tania)" was highlighted in the QCAmap environment and the thematic unit was labeled as the theme tools to conduct distance learning. The interview transcript section "I have not done many video lessons. Maybe I should. I think I have not been brave enough or have not known how to do it. I do not know how, or do not know how to do it on my own, I do not know how it works. And well, the thing is that I am not sure how to prepare a normal video lesson, in a way that it actually has a point too (Elisa)" was labeled as the theme teachers digital competence. The differences were discussed between researchers until a consensus was reached.

In the next stage, building hierarchies of themes took place-the themes with a similar content were grouped into larger units. For example, the themes tools to conduct distance learning and teachers digital competence (outlined above), together with the theme internet connection quality were grouped under the main theme "The existence of digital tools, their use and digital competences" (sub-theme teacher-related factors). Themes such as the number of computers per child, internet connection quality and students' digital competences, were also grouped under the main theme "The existence of digital tools, 
their use and digital competences" (sub-theme student-related factors). In the further analysis of the thematic units within the topic, the factors related to students and teachers were differentiated. These were divided into two sub-themes: teacher-related factors and student-related factors (examples above). Similar to the example above, two other themes, "Supporting social interaction and motivation" and "Students' and teachers 'workload and well-being", were formed by merging similar thematic units and labeled themes. As both student-related factors and teacher-related factors were differentiated in the thematic units for the second and third theme, the themes were further divided into sub-themes within the topics. In the results chapter, the results of each theme are presented in two divisions (student-related factors and teacher-related factors).

To ensure consistency in the interpretation of the analyzed text, two authors undertook parallel coding and theme-building. There was a continuous reflective discussion between the researchers in order to reach consensus on disagreements and thus increase the quality of the study.

During the data analysis process, the authors compiled a compact transcript of subthemes and themes, as recommended by Braun and Clarke [46], into the researchers' diary. The summaries supported the researchers' discussions in categorization and also in writing the results.

\subsection{Ethical Considerations}

A researcher is always obliged to protect the people participating in their research $[47,48]$. Hence, researchers should follow a number of key principles when designing and conducting a study, as well as presenting the results. For example, to minimize the risk and harm, to respect individuals' rights and dignity, to ensure that participation is voluntary and that the participant is adequately informed about the study, and also to conduct the study impartially, transparently and honestly [47]. The authors of this article followed these principles when designing, conducting and presenting the results of the study. Participants in the study were informed about the purpose of the study both by arranging a time for the interviews and before the start of the interview. Prior to the start of the interview, data retention and further use were explained. The structure of the interview was also introduced. In addition, subjects were offered the opportunity to ask additional questions and were informed that they had the right to refrain from answering the questions at any time during the interview and to end the interview at their own request. Participants were asked for permission to record interviews. Informed consent was obtained from all the subjects involved in the study.

In addition, to protect the privacy of the subjects and to ensure that the subjects were not identifiable when presenting the results, the names of all subjects and the names of the schools they named were replaced by pseudonyms during the transcription process. Names and pseudonyms were stored as a separate document and only two researchers (the authors responsible for data analysis) had access to the document. Pseudonyms were also used in the communication between the researchers during the analysis of the interviews. We also considered that the audio recordings and transcripts of the interviews would be available only to the researchers who performed the data analysis. Although the study was funded by the Estonian Research Council (ERC), it did not affect the results of this study. The researchers were independent throughout the study and there were no conflicts of interest brought on by the funding.

\section{Results}

The presented results follow the identified themes and sub-themes and are supported by extracts from the interviews. To illustrate and confirm the results, the pseudonym of the interviewed teacher is added after the attached extracts. Before presenting the results of the study, we consider it important to point out that the results are presented based on teachers' descriptions of the teaching experience during the distance learning period. 
It emerged from the interviews that in general, three main themes influenced the teachers' decisions regarding their teaching:

- The existence of digital tools, their use and digital competences;

- Supporting social interaction and motivation;

- Students' and teachers' workload and well-being.

Of the themes that emerged in data analysis, it in turn became evident that it was possible to distinguish (1) student-related factors and (2) teacher-related factors. Therefore, the results of each theme are presented in two divisions and next to the factors influencing teaching-related decisions, the ways these decisions were reflected in the teaching process during distance learning (based on teachers' explanations) are presented.

\subsection{The Existence of Digital Tools, Their Use and Digital Competences}

Student-related factors. Distance learning was preceded by a day of classroom training where teachers had the chance to give students guidelines regarding the distance learning period. According to the teachers who participated in the research, they also tried to figure out if the students had necessary technological means (especially a computer) at home already on the last classroom training day as well as the first distance learning week. Computers or tablets were lent out by the school if needed.

The number of computers per child was an important factor that influenced the teachers' decisions. When making decisions regarding teaching during distance learning, the participants considered that in some families, many children used the same computer (or that there was only one computer in the family). That means that it was important to try and avoid coinciding video lessons, because it might have not been possible for several children of the same family to participate in online lessons at the same time. Very strict deadlines of tasks were also brought out in the interviews as a concern. It was explained that such deadlines were given up on based on the feedback from both students as well as parents, because students might have not always had the chance to submit their work by the given time if they had to share a computer with other family members.

We thought of the situation where for example a family has three children, but only one computer. We cannot assume that everyone has a computer. In that case it is very hard to organize things in a way that everyone can submit their tasks by a certain time. Sometimes the children slept longer and maybe did their tasks at 8 PM, or however it was expected at home. We did not set any punctual deadlines. (Anita)

It also emerged from the interviews that the internet connection quality at the students' homes affected the teachers' teaching-related decisions during distance learning. It was said that there were students who could not participate in video lessons due to an unstable internet connection at home. For this reason, video lessons were implemented less rather than more at the beginning of the distance learning, teachers also brought up that they tried to reduce the students' screen time. Thus, alternative learning materials and ways (e.g., textbook/workbook tasks) were provided according to the participants.

Right when the first week had passed, feedback was asked from both parties and students brought out they did not want punctual deadlines. Many students did not have good digital solutions, for example their internet connection was bad. (Harriet)

Just that if the child really has to be in a video lessons for three-four hours straight. That is quite tiring as well. (Elisa)

No direct changes were made concerning the learning plan when considering students' digital competences. Participants found the students' digital competence to be rather good, but made sure to offer different environments to submit homework. However, teachers explained that at the beginning of distance learning it was necessary to give feedback to messages containing homework in order to identify whose work was received. It was pointed out that students needed some guidance on different digital environments at first. 
Well, one student sent me a letter containing just some picture of a workbook, nothing more. Then I sent them back a polite letter about how they had sent me this letter and if it was junk mail. The next time, the same student sent me a better version, one where they started with a "Hello" and "I am ...", which was a bit better. (Anita)

Teacher-related factors. Most of the teachers participating in the research found they had the necessary tools to conduct distance learning as well as sufficient internet connection quality and digital competences already at the beginning of the distance learning period. Many teachers pointed out they had just recently had training on the topic of digital skills and that now they could put what they had learned into practice. It was also said that the schools' IT specialists were happy to show how to use sites for communication (e.g., Zoom, Teams) or would provide digital tools. Therefore, when it came to making decisions about teaching, the teachers' possibilities to use digital tools and their digital competences were not brought out as a constraint. It was said that the teachers were given free choice to use digital environments and technology during distance learning.

I am in a very good situation, as I went to the school's computer teacher and they set up a second monitor for me, so I work from home with two screens and I also have a document camera. I am not complaining, I have the technical tools. (Tania)

Well, the school's management did not put any restrictions on us. When distance learning started then they said that tasks have to be doable for the students. That we should give a longer deadline in order not to overburden the students and to give them a chance to do things with their own pace. (Mary)

However, it became evident that, in two cases, teachers felt that their teaching-related decisions were restricted by either their digital competences or internet connection quality. One teacher explained that she decided not to implement video lessons because of being insecure in using digital environments or of being in front of the camera. Another teacher justified not implementing video lessons by avoiding the pressure on herself due to an unstable internet connection at home.

I have not done many video lessons. Maybe I should. I think I have not been brave enough or have not known how to do it. I do not know how, or do not dare to do it on my own, I do not know how it works. And well, the thing is that I am not sure how to prepare a normal video lesson, in a way that it actually has a point too. (Elisa)

\subsection{Supporting Social Interaction and Motivation}

In addition to digital tools (including their use and digital competences), the interviewed teachers said they considered supporting student motivation and social interaction as a part of it, when making teaching-related decisions during the distance learning period. The participants understood as teachers that students had limited possibilities for physical contact with other people in distance learning conditions, which is why opportunities for students' socializing were considered important. When it came to motivating students, it was perceived more or less the same as it would have been in a classroom setting. Although, the participants said they were more aware of motivating students and found themselves to be more intense about it during distance learning.

Student-related factors. It emerged from the interviews that teachers started carrying out video lessons in order to support students' social interaction (and motivation). It was explained that it was very important for the teachers that students could see and hear each other. Some of the participants described having breaks during the video lessons, just to talk on everyday topics-in this case, students' interactions with each other were perceived more important than reaching learning goals. In addition, several teachers were said to have allowed their students to talk to each other at the beginning and end of the lesson (similar to lesson breaks at school). The participants who also work as class teachers offered students separate times for interacting (homeroom in Zoom, Teams or Google Meet).

Usually about 10 to 15 min before class I give my students a link where they can log in.

Then I say it is break time now so you can speak. It is just so cool-oh, what do you have 
there? Show me as well! And then this kind of a social life starts to happen and after the lesson ends, I also say they have a 15 min break. This shows that even online lessons allow such socializing to happen. (Tania)

Then again, some teachers described situations where students did not want to switch on their cameras, making the teachers unsure if these students were actually participating. In these situations, supporting social interaction was perceived to be more difficult as well. There were teachers who encouraged students to switch on their cameras, but there were also those who came to terms with the fact that some students preferred to participate without a video picture.

Some switch their camera off, some mute themselves, how will I know what they are actually doing. If I ask them personally like hey, what do you think of this or that thing, just to get a discussion going, it is actually an obstacle. Some classes are completely silent, and I do not know if the students are even there, if they are listening or playing a game at the same time. So it is sort of an obstacle. (Tania)

To keep the students motivated and to support them, putting together methodologically diverse tasks and giving students a choice about how to submit their tasks were also brought out. The participants found that the learning materials as well as the learning activities expected from students had to be more diverse. For example, some teachers gave the students an option to do pair or group work, with the aim of supporting those who would be motivated by working together with someone else. In regards to learning materials, teachers offered the chance to learn the current topic through video material (e.g., YouTube learning videos), reading material or electronic materials, for all students to have a chance to find a learning path that suits them. Moreover, most of the teachers were said to have offered submitting students' homework in different forms (either on paper, as a picture, by email, e-School/Stuudium or any other site).

When putting together worksheets, I tried to put interesting things into the introduction, for the student not to lose interest, for them to have something to inspire them. In class, it is possible to do the introduction at the beginning of the lesson, to tell them why we are doing certain things. But being at home, if they are not able to participate in the Zoom class, they still need to be motivated. (Hilary)

I have given a free choice whether you do it on a paper, in Word or onto a homepage. It is more about me getting the completed task, rather than not getting it at all from the student. It might be the way that I have left it open for the students. (Aron)

Furthermore, teachers gave in a bit when it came to study results and graded students less strictly than usual. The teachers explained that in the context of distance learning it was more important that the students were motivated to work rather than just get good grades, which is why they were graded less strictly or the grading threshold was lowered. However, giving feedback to students was perceived to be more important than during classroom learning. The teachers said they understood that students needed motivating feedback for all of their actions during the distance learning period in order to study effectively. Private lessons were carried out with the students in need of extra support in learning as well.

For example, there was an agreement on the grading that there could definitely be a graded test on those topics that were studied before distance learning started. But during distance learning teachers were advised to be a bit less strict, maybe not grade everyone so much and rather give formative feedback. (Martin)

Lastly, teachers said they took students' opinions into account more during distance learning. Students' feedback about used study methods and ways of teaching was considered when planning the teaching in order to come up with solutions best suited for the students. For example, classes were asked if they wanted video lessons or whether they preferred digital solutions, tasks from their books or workbooks. According to the participants, the majority vote in the class was taken into account and if possible, the expectations 
were met. It was pointed out that several schools also asked for the feedback of the parents in order to consider their opinions during the distance learning period as well.

Now I ask the students more about how the lessons went, what to do again, what seems exciting, what they liked and what not. There is more feedback than in usual school lessons. They either write it down or we discuss it in Zoom lessons. (Harriet)

Teacher-related factors. Several teachers brought out that the decisions regarding the support of social interaction were not only prompted by the student-related factors as they themselves missed the face-to-face communication with their students as well. On the other hand, one of the participants felt that his own lack of motivation restricted supporting the students' social interaction and motivation. Therefore, the reasons why, for example, video lessons were conducted, also derived from the teachers' own preferences.

It is hard to work from home like that. Well, I do not live alone, I have a partner and to organize life like this right now is rather difficult, because my partner does not currently work and being together here like this, I just do not know. I could do these things [video lessons, individual tutoring], I have thought about it, but for some reason I cannot start doing it. I do not know, my own motivation has decreased. (Henry)

\subsection{Students' and Teachers' Workload and Well-Being}

Student-related factors. According to the participants, when making teaching-related decisions during distance learning, taking the students' workload into account was of higher importance than beforehand, during classroom learning. They explained that distance learning was a new experience for the students and the society was more anxious as well. Feedback about students' workload was gathered systematically school-wide or by teachers. The feedback revealed that students' workload had increased during distance learning - it was decided to reduce their workload to improve their general well-being.

I had a hunch about how the students' workload might increase during distance learning, which is why I organized my teaching in a way that the students did not have to do something every day, I gave assignments they had to complete by the end of the week, or next week. (Henry)

The participants said they had freedom about which digital environments to use and in general there were no within-school agreements about that. As a result, the teachers found that students needed extra time in the first few weeks to get used to the different environments, which in turn increased the students' workload. It became clear during the first weeks of distance learning that students' work pace and abilities to independently study were very different, which is why their workload was reduced, their work pace was slowed down, and smaller goals were set. A few of the participants, however, mentioned having virtual meetings to discuss and agree on which sites (e.g., Zoom, Teams, Google Meet, Google Classroom) to use within-school or just to give each other tips and tricks.

We have different meetings for different subject fields at our school. We talk about what we use with which class. We show things that work well with some classes and then give tips to each other about what should be changed and what not. (Harriet)

Only a few interviewees said that they cooperated with other teachers in their subject when giving tasks, for example during one school day or week or in general giving intertwined tasks. However, the interviewees expressed that they kept it in mind that students had other subjects besides their own as well. Several teachers mentioned that in natural sciences (in comparison to for example mathematics) it is easier to acquire the missing topics when classroom teaching resumes, which is why reducing learning outcomes was not perceived to be critical. It was also found that if students are not in their senior year and the same students continued with the same teacher next year, then it is possible to know exactly what was not learned and it is possible to add the necessary topics into the work plan. 
I considered the fact that students are people as well and they have other subjects too. If they only had my subject, I would have given them more to do. But well, let us be realistic and look at their abilities. (Evie)

Teacher-related factors. In addition to students' workload and general well-being, the teachers' own workload and well-being influenced their teaching-related decisions. All the teachers who were interviewed said that their own workload affected the decisions they made about teaching during the distance learning period.

Most teachers claimed they started distance learning with enthusiasm and tried to be there for the students at all times, including giving individual feedback. They communicated with students through e-School/Stuudium early in the morning as well as late at night - the main thing was that the students would understand the topic they were learning and would feel that the teacher was there for them.

Some send their homework in at half past 7 PM, some send theirs at half past 10 and add a comment about if what they are sending is correct and if they need to make any changes.

I usually replied instantly, because maybe later on they will not bother to do it anymore.

I could not do it in any other ways, this seemed right to me. (Tania)

The participants explained that after working like this for a few weeks it was clear that it was not possible to continue that way. Such active teaching and thorough feedback for students increased their workload and there was a danger of burnout. Because of this, teachers tried to teach in a way that would let them "survive", but so that the minimum goals would still be met even during distance learning. They tried to find the balance between the learning process and preserving themselves. Many participants started doing video lessons during that period to explain topics that were more difficult face-to-face and through that reduce individual feedback and the need for teaching something over again.

I thought that it is important to give students a lot of good feedback and in the first weeks we heard back that getting quick feedback was appreciated. At some point though I felt that I am not capable of working like this anymore. (Harriet)

According to the teachers who participated in the research, in order to reduce their workload (for self-care), they reduced the work pace and workload in general. They taught topics that were feasible for the students, the goal was to just teach the most important topics and/or the topics were not taught in that great of a detail. They also found a way to reduce workload by assigning pair or group work, which decreased the amount of completed tasks that needed feedback. It was brought out that teachers started giving more general feedback instead of individual feedback, for example feedback for the whole class (e.g., in a Zoom class). Teachers who created study videos said they reduced the amount of videos and instead encouraged students to acquire the topic through reading material. Students were given long-term tasks to reduce the papers teachers had to check.

At some point I felt I also needed my own personal time. I realized I had put the deadlines too close to each other and started spreading them out a bit. (Marion)

One day I counted I had given different classes about 140 papers. I discussed it with the head teacher and we concluded that it is not wise to give individual feedback to all the papers. The students need to have some responsibility as well. (Aron)

One of the participants had their students do group work for weeks during distance learning and did not conduct any video lessons. As a result of that, the teacher perceived his workload to be significantly lower. Among other reasons, he justified his decision with the thought that teachers were given a lot of freedom regarding their teaching during distance learning, which enabled this little communication with the students.

It seemed easier for both the students and me. As I did not have this everyday contact with them anymore, I found it really hard to work from home. I was a little mentally drained from all the work in school as well and needed time for myself too. (Henry) 
The results of both research questions are concluded in the following Table 2, which therefore presents what teachers pointed out as important factors influencing their teachingrelated decisions during distance learning and how were these decisions were reflected in the teaching process.

Table 2. The factors influencing teachers' teaching-related decisions and how were these decisions reflected in the teaching process.

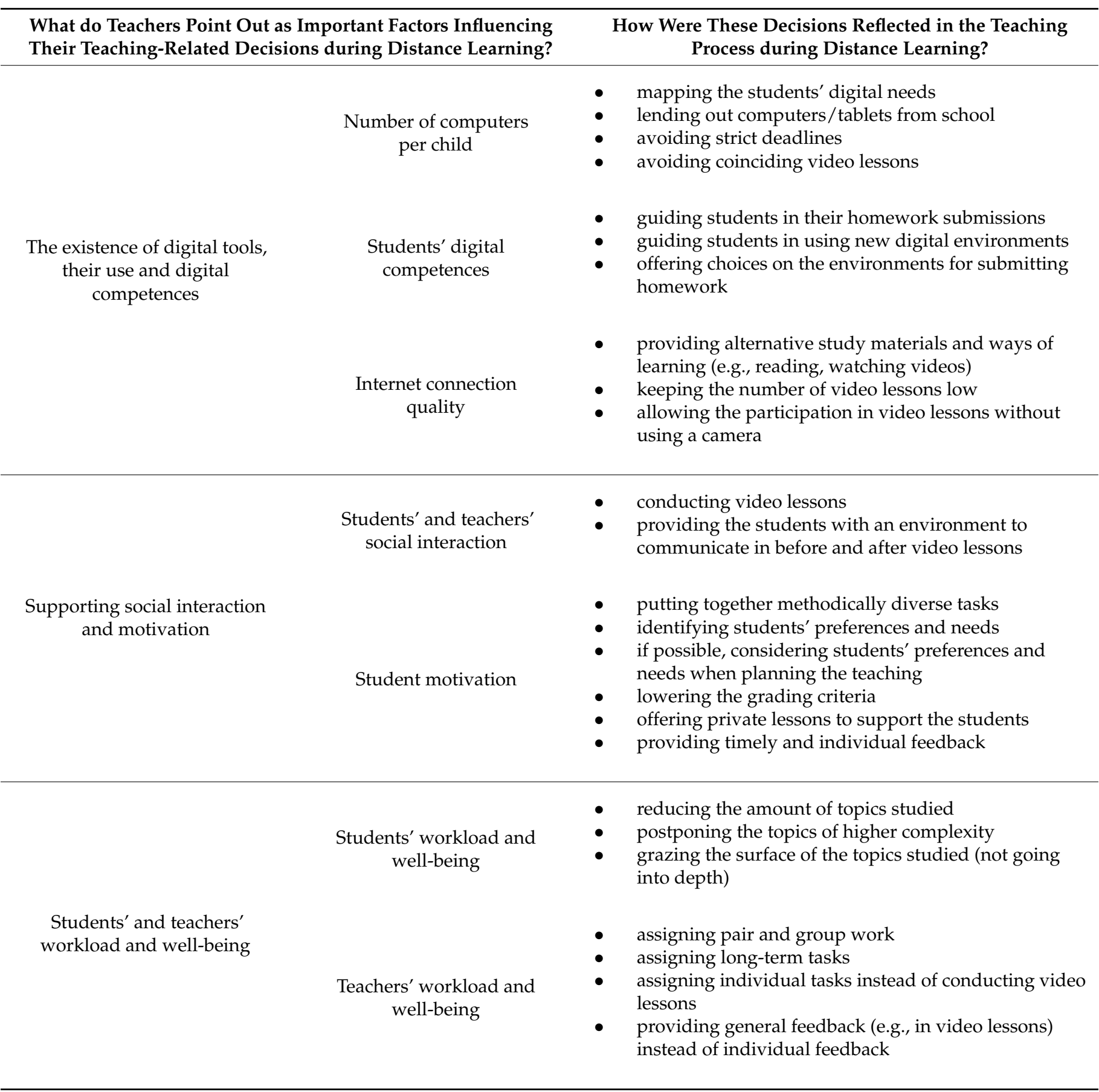

In conclusion, it can be said that the teachers' teaching-related decisions in the context of distance learning were influenced by factors connected to both students and teachers themselves. Teachers had to consider which digital tools were needed to teach, as well as to study and they had to think of how different families dealt with sharing those tools with each other and whether the internet connection quality made it possible to use them. 
The existing equipment and solutions allowed teachers to teach, but there were some teachers whose own digital competence and their lack of courage to use the camera or the quality of their internet connection put some limits on their teaching-related decisions. The participants said that their teaching-related decisions were also influenced by their wish to motivate students and offer them a chance to socialize face-to-face even in conditions of distance learning. In addition, the wish to reduce students' workload (and through that increase their overall well-being), as well as the teachers' workload in the name of self-care were brought out as important factors that influenced teaching-related decisions. To ensure both student motivation and well-being, the number of topics covered in teaching was reduced and teachers did not aim to go as deeply into the topics as they would have done in traditional classroom contact teaching.

\section{Discussion}

The aim of this study was to describe and explain what influenced the teachers' teaching-related decisions and how these decisions were reflected in the teaching process during distance learning (according to teachers themselves). In the following, we discuss some of the main results in the perspective of previous research.

Contrary to findings from several other studies $[3,4,7,8]$, teachers' and students' digital competences were not perceived as a restriction on teaching-related decisions by the teachers in the current study. The teachers found (with two exceptions) they had the necessary tools and skills to conduct distance learning effectively and perceived their students' digital competence as rather good. Thus, from the viewpoint of students' digital competences, the results are in accordance with previous studies. For example, the results of the PISA survey show that Estonian children are in general satisfied with their digital skill sets [42].

The results of the current study also clearly support that "A digital focus in lifelong learning" in Estonian Lifelong Learning Strategy 2020 [38] has successfully been implemented in the Estonian education system. However, these results are surprising since previous research has indicated a more modest level of Estonian teachers digital competences. For example, Leppik et al. [39] research shows that Estonian teachers perceive their digital competences as rather poor and the (author(s)) [43] study also showed that smartphones and tablets have not been used very often in learning science. Furthermore, the results contradict the findings of the Teaching and Learning International Survey TALIS 2018 conducted by OECD [40], according to which only a little over a half $(63,1 \%)$ of the Estonian school principals believe that most of their teachers feel confident using ICT tools in teaching their subject. One possible explanation for such a positive result could be the fact that the teachers themselves (and also school leaders) have been too critical of teachers' digital skills and that the actual level of skills is better than previously perceived and enables teachers to cope well with distance learning using digital tools. Another possible explanation could be the fact that the teachers had been teaching at a distance for more than a month at the time of data collection. Thus, by that time, their digital competences may indeed have been sufficient for putting technology in good use for learning. Another interpretation is related to the teachers' autonomy of making decisions regarding the use of different digital solutions in distance learning conditions. It is possible that the teachers decided in favor of the digital solutions (and environments) they felt confident using and excluded the ones for which they did not have sufficient skills, even if learning and giving feedback could have been more effective through the solutions unfamiliar to the teachers. As the results of this study also show that the teachers were concerned about providing individual feedback to students (related to their workload), there may still be a need to analyze teachers' digital competences in this matter and if necessary, to support teachers in their ability to make the available technological tools suitable for the learning process as has also been pointed out in previous studies (e.g., $[7,8])$. The elaborate use of technological, pedagogical and subject knowledge as brought out by Mishra and Koehler [19], enables teachers to use digital solutions for learning in the most effective way possible. 
The results also showed that teachers asked students for feedback on both the study methods used and the ways of teaching, and took the students' opinions into account (according to themselves) more than before, in the case of classroom learning. In teachers' estimation, students were also given more choices in the ways of learning (individual-pair work) as well as in the submission of their tasks (through different environments). Identifying students' preferences and giving choices is certainly supportive of students' learning motivation and at the same time important in supporting students' self-management skills [18]. Thus, a positive impact of distance learning can too be seen on teachers' teaching-related decisions (and the accompanying activities). The reason why teachers are said to have taken students' feedback into account more than usual may be because by seeing students face-to-face in a classroom situation, the teacher directly perceives (based on previous experience and knowing his/her students in this situation) the study methods preferred by students and apprehends which of those is appropriate to use in that specific moment. However, in the distance learning conditions, the possibility for visual contact was decreased and thus the teachers' data for making pedagogical decisions reduced as well, which may have increased the need for more extensive direct feedback from students. This raises the question of whether asking students directly for feedback, as well as giving them more choices, is something that should be included in further teaching, by systematically combining the teachers' experiences and interpretations from classroom observations with systematically gathered feedback from the students. It would be interesting to find out, from the perspective of both teachers and students, whether the attitudes and activities regarding these aspects changed after returning to classroom learning after the end of distance learning caused by COVID-19.

Maintaining social interaction between students and teachers was also considered while making teaching-related choices in distance learning conditions. The participants considered socializing to be of higher importance than reaching subject matter related to learning goals in some situations. The results are in good accordance with the guidelines provided at a national level at the beginning of distance learning, which emphasized the need for supporting students' social interaction [35]. In most cases, the teachers who participated in the study tried to support the students' need for social interaction through video lessons, where students had the opportunity to see each other. However, it was also described that not all students switched on their cameras during video lessons. Such situations were described as uncomfortable for the teacher because on the one hand, it was insecure (the teacher could not see who was behind the screen), but on the other hand the lack of control over the students' activities was pointed out. Rannastu-Avalos and Siiman [49] have also stated that video lessons lose a significant part (presumed advantages for establishing social presence) if students do not turn on their cameras. It is possible that explaining and discussing why participation in this way is important for both students and teachers could help to change students' behavior.

As of interesting results, we also point out the ingenuity of teachers to create opportunities for students to communicate in between lessons in the conditions of distance learning - the so-called distance learning lesson breaks. This could be an idea that could be recommended to teachers when teaching at a distance. At the same time, it is important to keep the issue of privacy and security in mind for both the lessons and the "distance learning lesson breaks". Although digital security is considered as an important issue in teachers' digital competencies and is addressed in Estonian teacher training as well as in in-service training, legal solutions on how distance learning would work correctly from a data protection point of view have been rather delayed and sometimes controversial. For example, a letter from the Data Protection Inspectorate to schools (October 2020) states that "in our opinion, observing students through real-time video images is justified, so that the teacher can conduct the lessons, including checking the students' participation in the lesson. Thus, the teachers are allowed to oblige the students to share their video images" [50] (p. 2). At the same time, from a lawyer's point of view, Krookmaa [51] has outlined (December 2020) a number of reasons related to data protection laws as to why keeping the camera on 
for an entire lesson is an infringement of private law and should not be required. Therefore, from the point of view of both students and teachers, it would be important to clearly state the appropriate behavior in relation to the nuances of data protection and cyber security, while considering how the benefits of students and teachers seeing each other in learning situations can be provided. This should be followed by training and/or informing teachers of the behaviors agreed on in a timely and comprehensible manner.

Lastly, we discuss the results in terms of workload and well-being. According to the participants, both students' and teachers' workload and well-being were considered while making teaching-related choices. Previous research in the context of COVID-19 has also shown that uncertainty [9], the workload of teachers $[6,49]$ and general teachers work-related stress $[8,10]$ has increased in distance learning settings, and this has also affected teachers' teaching practice. According to the teachers themselves, they applied a number of activities to reduce the workload of the students during the distance learning period (e.g., reducing the amount of topics studied, postponing more difficult topics to next year, just grazing the surface of the topics studied, giving long-term assignments), because it was understood that it takes more time for the students to learn independently and also that the students' learning skills are different. The teachers perceived the well-being of the students to be of higher importance than reaching the maximum learning outcomes related to subject matter prescribed in the curriculum, especially since the emergency situation (due to COVID-19) had already caused a lot of anxiety among people. In this regard, the teachers who participated in the study have considered the guidelines provided by the Ministry of Education and Research [35] rather well at the beginning of distance learning. For example, such guidelines as giving students more time to complete their tasks and considering that students' learning habits and abilities to work independently are different were taken into account by the participants when making teaching-related choices. In the short-term perspective, where in the spring of 2020 the situation of distance learning lasted for a rather short period of time (under three months), such an approach was understandable in the opinion of the authors. However, while COVID-19 continues to show no significant signs of regression (at the end of 2020), it is important to analyze which learning outcomes should be achieved according to the curriculum, regardless of the form of learning in schools and furthermore, at a national level. As the current situation in education also affects students' options for further education (e.g., entry to the next level of education) as well as their compliance with the expectations of future employers, a basic level of knowledge should be agreed on that is required and achievable in distance learning conditions. This is related to reconsidering the long-term purposes of education as proposed by Biesta [11] and specifying more clearly how to reach them.

The teachers who participated in the study pointed out that as their own workload increased during the transition to distance learning (similar to the study by RannastuAvalos and Siiman, [49]), students were given, for example, pair or group work, the deadlines of assignments were extended, and the amount of individual feedback was reduced. Thus, the students and factors related to them were no longer behind the teachingrelated decisions, but instead the well-being of the teachers themselves were. On the one hand, however, such an outcome can be seen as positive, since pair and group work supports the development of students' social skills and long-term assignments allow students to develop self-management skills, as pointed out by Eggen and Kauchack [18]. It is certainly important that, in addition to the students' emotional well-being, the teachers' well-being is taken into account as well in teaching and teaching-related choices. For example, Reimes and Schleicher [36] have pointed to the need to support and think of the teachers' emotional well-being in the context of COVID-19. At the same time, the question arises as to what is the good balance between ensuring the well-being of the teacher and ensuring that the teachers' pedagogical decisions support each student's development to the maximum in distance learning conditions.

Finally, results from the current study confirm findings from a previous study showing that teachers tend to focus on short-term goals in their teaching and more rarely consider 
the long-term purposes of education [21], in this sense the findings are not so different from the data collected from regular (pre-COVID) teaching times. However, what seems to be unique for this new situation is the switch of focus to workload and well-being and valuing socialization and student motivation over subject matter competences. Although this indicates student-centeredness, which is genuinely valued in today's education [18], this might also have serious implications for student learning outcomes in the long run. Continuing with the organization of education in such a way might increase inequalities in education as it could become even harder for students from disadvantaged backgrounds to develop their academic competences. Therefore, it is very important not to lose sight from the third important aim of education, qualification [11] for the next level of education or for working life and to ensure that different students have more equal opportunities for this. It is important to take all this into account in teaching decision-making processes, regardless of where or in what form learning and teaching take place.

\section{Conclusions}

In this article we described and explained what influenced science teachers' teachingrelated decisions and how learning activities were adjusted based on these decisions during distance learning (according to teachers themselves). The results show that teachers' teaching-related decisions were influenced by factors that were related to the existence of digital tools as well as the ability to use them purposefully in the home settings of teachers and students. Teachers' teaching decisions were mostly motivated by short-term goals, such as maintaining students' social interaction and more broadly, supporting student motivation in this irregular situation. In addition, the desire of teachers to keep students' and teachers' own workloads affordable, for the purposes of well-being, was also considered as a factor influencing teachers' teaching-related decisions. In brief, this study contributes to the understanding of teachers' decision-making processes during distance learning, introduces the adjustments made in learning activities and discusses potential implications for such practices. In further research, it would be important to use method triangulation, collecting observational data in addition to interviews for example, to understand further how teachers' decision-making is reflected in teaching and learning activities and its outcomes. Data on students' views could also be valuable additional information to further understand the changed teaching and learning.

Author Contributions: Conceptualization, T.A., L.L., Ä.L. and M.P.; methodology, L.L., Ä.L., M.P. and K.S.; formal analysis, T.A. and L.L.; investigation, T.A., L.L., Ä.L., M.P. and K.S.; resources, L.L., Ä.L., M.P. and K.S.; data curation, T.A. and L.L.; writing-original draft preparation, T.A. and L.L.; writing-review and editing, T.A., L.L., Ä.L., M.P. and K.S.; supervision, L.L.; project administration, M.P.; funding acquisition, M.P. All authors have read and agreed to the published version of the manuscript.

Funding: This research was funded by the ESTONIAN RESEARCH COUNCIL (ERC) through the institutional research funding project "Smart technologies and digital literacy in promoting a change of learning", grant number IUT34-6.

Institutional Review Board Statement: Not applicable.

Informed Consent Statement: Informed consent was obtained from all subjects involved in the study.

Data Availability Statement: The data presented in this study are available on request from the corresponding author. The data are not publicly available due to privacy or ethical restrictions.

Acknowledgments: The authors would like to thank all of the participants who took their time to take part in this research.

Conflicts of Interest: The authors declare no conflict of interest.

\section{References}

1. World Health Organization. Coronavirus Disease (COVID-19). Available online: https://www.who.int/emergencies/diseases/ novel-coronavirus-2019/question-and-answers-hub/q-a-detail/coronavirus-disease-covid-19 (accessed on 5 January 2021). 
2. UNESCO. COVID-19 Impact on Education. Available online: https://en.unesco.org/covid19/educationresponse (accessed on 5 January 2021).

3. Cullinane, C.; Montacute, R. COVID-19 and Social Mobility Impact Brief \#1: School Closures. Available online: https://www. suttontrust.com/wp-content/uploads/2021/01/School-Shutdown-Covid-19.pdf (accessed on 4 January 2021).

4. Schuck, R.K.; Lambert, R. “Am I Doing Enough?” Special Educators' Experiences with Emergency Remote Teaching in Spring 2020. Educ. Sci. 2020, 10, 320. [CrossRef]

5. Bubb, S.; Jones, M.A. Learning from the COVID-19 home-schooling experience: Listening to pupils, parents/carers and teachers. Improv. Sch. 2020, 23, 209-222. [CrossRef]

6. Kaden, U. COVID-19 School Closure-Related Changes to the Professional Life of a K-12 Teacher. Educ. Sci. 2020, 10, 165. [CrossRef]

7. Gudmundsdottir, G.B.; Hathaway, D.M. 'We Always Make It Work': Teachers' Agency in the Time of Crisis. J. Tech Teach. Educ. 2020, 28, 239-250. Available online: https:/ / www.learntechlib.org/primary/p/216242/ (accessed on 4 January 2021).

8. Trust, T.; Whalen, J. Should Teachers be Trained in Emergency Remote Teaching? Lessons Learned from the COVID-19 Pandemic. J. Technol. Teach. Educ. 2020, 28, 189-199. Available online: https://www.learntechlib.org/primary/p/215995/ (accessed on 4 January 2021).

9. Kim, L.E.; Asbury, K. 'Like a rug had been pulled from under you': The impact of COVID-19 on teachers in England during the first six weeks of the UK lockdown. Br. J. Educ. Psychol. 2020, 90, 1062-1083. [CrossRef]

10. MacIntyre, P.D.; Gregersen, T.; Mercer, S. Language teachers' coping strategies during the Covid-19 conversion to online teaching: Correlations with stress, wellbeing and negative emotions. System 2020, 94, 102352. [CrossRef]

11. Biesta, G. Good education in an age of measurement: On the need to reconnect with the question of purpose in education. Educ. Assess. Eval. Account. 2009, 21, 33-46. [CrossRef]

12. Schleicher, A. PISA 2018: Insights and Interpretations. Available online: https://www.oecd.org/pisa/PISA \%202018\%20Insights\% 20and\%20Interpretations\%20FINAL\%20PDF.pdf (accessed on 4 January 2021).

13. Sonmark, K.; Révai, N.; Gottschalk, F.; Deligiannidi, K.; Burns, T. Understanding Teachers' Pedagogical Knowledge: Report on an International Pilot Study. Available online: http:/ / www.oecd.org/education/ceri/EDU_WKP(2017)8.pdf (accessed on 5 January 2021).

14. Lampert, M. Studying teaching as a thinking practice. In Thinking Practices in Mathematics and Science Learning; Greeno, J.G., Goldman, S.V., Eds.; Lawrence Erlbaum Associates, Inc: Mahwah, NJ, USA, 1998; pp. 53-78.

15. Vanlommel, K.; Van Gasse, R.; Vanhoof, J.; Van Petegem, P. Teachers' decision-making: Data based or intuition driven? Int. J. Educ. Res. 2020, 83, 75-83. [CrossRef]

16. Shulman, L. Knowledge and teaching: Foundations of the new reform. Harv. Educ. Rev. 1987, 57, 1-23. [CrossRef]

17. Shavelson, R.J.; Stern, P. Research on teachers' pedagogical thoughts, judgments, decisions, and behavior. Rev. Educ. Res. 1981, 51, 455-498. [CrossRef]

18. Eggen, P.; Kauchak, D.P. Educational Psychology: Windows on Classrooms, 9th ed.; Pearson Education: Upper Saddle River, NJ, USA, 2013.

19. Mishra, P.; Koehler, M.J. Technological pedagogical content knowledge: A framework for teacher knowledge. Teach. Coll. Rec. 2006, 108, 1017-1054. [CrossRef]

20. Borg, S. Teacher cognition in language teaching: A review of research on what language teachers think, know, believe, and do. Lang. Teach. 2003, 36, 81-109. [CrossRef]

21. Biesta, G.; Priestley, M.; Robinson, S. The role of beliefs in teacher agency. Teach. Teach. 2015, 21, 624-640. [CrossRef]

22. Fives, H.; Buehl, M.M. Spring cleaning for the "messy" construct of teachers' beliefs: What are they? Which have been examined? What can they tell us? In Educational Psychology Handbook, Vol. 2: Individual Differences and Cultural and Contextual Factors; Harris, K.R., Graham, S., Urdan, T., Eds.; American Psychological Association: Washington, DC, USA, 2012; pp. 471-499.

23. Lepik, M.; Elvisto, T.; Oder, T.; Talts, L. Õpetajate üldpedagoogiliste uskumuste struktuur ja tüüpprofiilid. Opet. Prof. Areng Ja Selle Toetamine 2013, 248-273. Available online: https: / /www.digar.ee/arhiiv/et/raamatud/22182 (accessed on 4 January 2021).

24. Raymond, A.M. Inconsistency between a beginning elementary school teacher's mathematics beliefs and teaching practice. J. Res. Math. Educ. 1997, 28, 550-576. [CrossRef]

25. Henno, I.; Granström, S. Ülevaade aineõpetajate ja koolijuhtide veebiküsitlusest "Uutest riiklikest õppekavadest lähtuv kooliõppekavade arendus ja rakendamine". Available online: https://dspace.ut.ee/bitstream/handle/10062/40934/Uld_ Koolijuhid_Veeb.pdf?sequence=1\&isAllowed=y (accessed on 3 September 2020). (In Estonian)

26. Sun, J.; Zhang, S.; Przybylski, R. Conceptualizing the Critical Path Linked by Collective Teacher Efficacy. In Proceedings of the Annual Meeting of the American Educational Research Association (AERA), San Antonio, TX, USA, 27 April-1 May 2017.

27. Aho, E.; Haverinen, H.L.; Juuso, H.; Laukka, S.J.; Sutinen, A. Teachers' principles of decision-making and classroom management; a case study and a new observation method. Procedia. Soc. Behav. Sci. 2010, 9, 395-402. [CrossRef]

28. Eisenschmidt, E.; Reiska, E.; Oder, T. Novice teachers' perception of senior management support and its connection with involvement in school development and collegial co-operation. Est. J. Educ. 2015, 3, 148-172. [CrossRef]

29. Kosko, K.W.; Herbst, P. Evaluating Teachers' Decisions in Posing a Proof Problem. In Proceedings of the 34th Annual Meeting of the North American Chapter of the International Group for the Psychology of Mathematics Education (PMENA), Kalamazoo, MI, USA, 1-4 November 2012. 
30. Epstein, J.L.; Sheldon, S. The importance of evaluating programs of school, family and community partnerships. Aula Abierta 2019, 48, 31-42. [CrossRef]

31. Leijen, Ä.; Pedaste, M.; Lepp, L. Teacher agency following the ecological model: How it is achieved and how it could be strengthened by different types of reflection. Br. J. Educ. Stud. 2020, 68, 295-310. Available online: https:/ /www.tandfonline. com/doi/full/10.1080/00071005.2019.1672855 (accessed on 4 January 2021). [CrossRef]

32. Haridussilm. Külastatud Aadressil. Available online: https://www.haridussilm.ee/ (accessed on 22 August 2020).

33. Basic Schools and Upper Secondary Schools Act. Available online: https://www.riigiteataja.ee/en/eli/ee/530102013042 / consolide/current (accessed on 19 August 2020).

34. National Curriculum for Basic Schools. Available online: https://www.hm.ee/sites/default/files/est_basic_school_nat_cur_20 14_general_part_1.pdf (accessed on 19 August 2020).

35. Haridus-ja Teadusministeerium Soovitab Vähemalt Esimesel Kahel Nädalal Hoiduda Õpilaste Numbrilisest Hindamisest. Available online: https://www.hm.ee/et/uudised/parandatud-teade-haridus-ja-teadusministeerium-soovitab-vahemalt-esimeselkahel-nadalal-0 (accessed on 18 March 2020). (In Estonian).

36. Reimers, F.M.; Schleicher, A. A Framework to Guide an Education Response to the COVID-19 Pandemic of 2020. OECD. Available online: https: / / oecd.dam-broadcast.com/pm_7379_126_126988-t63lxosohs.pdf (accessed on 9 August 2020).

37. We Have Built a Digital Society and We Can Show You How. Available online: https:/ / e-estonia.com/ (accessed on 19 August 2020).

38. The Estonian Lifelong Learning Strategy 2020. Available online: https://www.hm.ee/sites/default/files/estonian_lifelong_ strategy.pdf (accessed on 19 August 2020).

39. Leppik, C.; Haaristo, H.S.; Mägi, E. IKT-haridus: Digioskuste õpetamine, Hoiakud ja Võimalused Üldhariduskoolis ja Lasteaias; Poliitikauuringute Keskus Praxis: Tallinn, Estonia, 2017. Available online: http://www.praxis.ee/wp-content/uploads/2016/08/ IKT-hariduse-uuring_aruanne_mai2017.pdf (accessed on 3 September 2020). (In Estonian)

40. Taimalu, M.; Uibu, K.; Luik, P.; Leijen, Ä. Õpetajad ja koolijuhid elukestvate õppijatena. OECD rahvusvahelise õpetamise ja õppimise uuringu TALIS 2018 tulemused. 1. osa. Tallinn: Haridus- ja Teadusministeerium ja SA Innove. Available online: https:/ / www.hm.ee/sites/default/files/talis_eesti_raporti_i_osa.pdf (accessed on 4 January 2021).

41. Kutsestandardid: Õpetaja, Tase 7. Available online: https://www.kutseregister.ee/ctrl/et/Standardid/vaata/10824233?from= viimati_kinnitatud (accessed on 24 August 2020). (In Estonian)

42. Tire, G.; Puksand, H.; Lepmann, T.; Henno, I.; Lindemann, K.; Täht, K.; Lorenz, B.; Silm, K. PISA 2018 EESTI TULEMUSED Eesti 15-Aastaste Õpilaste Teadmised ja Oskused Funktsionaalses Lugemises, Matemaatikas ja Loodusteadustes. Available online: https: / / www.hm.ee/sites/default/files/pisa_2018-19_raportweb.pdf (accessed on 8 September 2020). (In Estonian)

43. Pedaste, M.; Must, O.; Leijen, Ä.; Mäeots, M.; Siiman, L.; Kori, K.; Adov, L. Profiles of students who use mobile devices for the purposes of learning science and mathematics. Estonian J. Educ. 2017, 5, 99-129.

44. Adov, L.; Pedaste, M.; Leijen, Ä.; Rannikmäe, M. Does it have to be easy, useful, or do we need something else? STEM teachers' attitudes towards mobile device use in teaching. Technol. Pedagog. Educ. 2020, 29, 511-526. [CrossRef]

45. Ryan, G.W.; Bernard, H.R. Techniques to identify themes. Field Methods 2003, 15, 85-109. [CrossRef]

46. Braun, V.; Clarke, V. Using thematic analysis in psychology. Qual. Res. Psychol. 2006, 3, 77-101. [CrossRef]

47. ESRC Framework for Research Ethics Updated January 2015. Available online: https://esrc.ukri.org/files/funding/guidancefor-applicants / esrc-framework-for-research-ethics-2015/ (accessed on 4 January 2021).

48. World Medical Association. World Medical Association Declaration of Helsinki: Ethical Principles for Medical Research involving Human Subjects. JAMA 2013, 310, 2191-2194. [CrossRef] [PubMed]

49. Rannastu-Avalos, M.; Siiman, L.A. Challenges for Distance Learning and Online Collaboration in the Time of COVID-19: Interviews with Science Teachers. In Proceedings of the 26th International Conference on Collaboration Technologies and Social Computing (CollabTech), Tartu, Estonia, 8-11 September 2020; pp. 128-142. [CrossRef]

50. Andmekaitse Inspektsioon. Ringkiri Koolidele. Available online: https://www.aki.ee/sites/default/files/seired/ringkiri_ koolidele_distantsope_jm_07.10.20_1.pdf (accessed on 7 October 2020). (In Estonian)

51. Kookmaa, T. Advokaat: Kas Distantsõpe Annab Õiguse Õpilaste Lausjälgimiseks? Available online: https://forte.delfi.ee/ news/varia/advokaat-kas-distantsope-annab-oiguse-opilaste-lausjalgimiseks?id=91966669 (accessed on 14 December 2020). (In Estonian) 